\title{
ETHICS AND PUBLIC HEALTH: DEFINITION OF PRIORITIES IN THE MEXICAN HEALTH REFORM
}

\author{
Octavio Gómez-Dantés ${ }^{1}$, Julio Frenk ${ }^{2}$
}

\begin{abstract}
The purpose of this paper is to discuss one of the most common ethical predicaments faced by public health practitioners: the distribution of limited resources for health. The question we address is the following: If there are limited resources to provide necessary health care, how can we reasonably establish priorities? We discuss this question using as reference a real-life situation, which was the establishment of priorities in the design of a package of high-cost interventions for Seguro Popular in Mexico, a public insurance scheme that extended social protection in health to over 50 million people between 2003 and 2018. The main conclusion of this paper is that the use of explicit ethical assumptions in the design of public policies contribute to their acceptability and eventual success.
\end{abstract}

Key words: ethics, definition of health priorities, health reform, Mexico

\section{Ética y salud pública: definición de prioridades en la Reforma Sanitaria mexicana}

Resumen: El propósito de este artículo es discutir uno de los dilemas éticos que con mayor frecuencia enfrentan quienes se dedican a la salud pública: la distribución de recursos limitados para la salud. La pregunta a la que se pretende responder es la siguiente: si existen recursos limitados para prestar los servicios de salud necesarios, ¿cómo podemos fijar prioridades? Intentamos responder a esta pregunta haciendo referencia a una situación de la vida real que fue el establecimiento de prioridades en el diseño de un paquete de intervenciones de alto costo para el Seguro Popular de México, un seguro público que extendió la protección social en salud a más de 50 millones de personas entre 2003 y 2018. La principal conclusión de este artículo es que el uso de un marco ético explícito en el diseño de las políticas públicas incrementa su aceptabilidad y favorece su eventual éxito.

Palabras clave: ética, definición de prioridades en salud, reforma de salud, México

\section{Ética e saúde pública: definiçáo de prioridades na Reforma Sanitária mexicana}

Resumo: O propósito deste artigo é discutir um dos dilemas éticos que com maior frequência aqueles que se dedicam à saúde pública enfrentam: a distribuição de recursos limitados para a saúde. A pergunta que se pretende responder é a seguinte: se existem recursos limitados para prestar os serviços de saúde necessários, como podemos fixar prioridades? Tentamos responder a esta pregunta fazendo referência a uma situação de vida real que foi o estabelecimento de prioridades na concepçáo de um pacote de intervençóes de alto custo para o Seguro Popular do México, um seguro público que estendeu a proteção social em saúde a mais de 50 milhóes de pessoas entre 2003 e 2018. A principal conclusão deste artigo é que o uso de um enquadramento ético explícito na concepção das políticas públicas aumenta sua aceitação e favorece seu eventual sucesso.

Palavras chave: ética, definição de prioridades em saúde, reforma da saúde, México

\footnotetext{
${ }^{1}$ Centro de Investigación en Sistemas de Salud del Instituto Nacional de Salud Pública de México, México. ORCID: 0000-0002-9602-3498 Correspondence: ocogomez@yahoo.com

${ }^{2}$ University of Miami, USA. ORCID: https://orcid.org/0000-0002-8760-7926
} 
Ethical discussions are common in clinical medicine. There is a vast literature on confidentiality in medical practice, the role of physicians in endof-life care, and many other relevant topics. In contrast, ethical dilemmas in public or population health have received less attention in the academic literature. The purpose of this paper is to discuss one of the most common ethical predicaments faced by public health practitioners: the distribution of limited resources for health. The question we will address is the following: If there are limited resources to provide necessary health care, how can we reasonably establish priorities?

We will discuss this question using as reference a real-life situation, which was the establishment of priorities in the design of a package of high-cost interventions for Seguro Popular in Mexico, a public insurance scheme that extended social protection in health to over 50 million people between 2003 and 2018. The main conclusion of this paper is that the use of explicit ethical assumptions in the design of public policies contribute to their acceptability and eventual success.

\section{Establishing priorities justly}

Some of the dominant ideas on the establishment of priorities in public policies derive from 'utilitarianism.' This moral theory states that actions should be considered wrong or right depending on their effects. Utilitarians believe that the purpose of morality is to increase the amount of good things in the world and decrease the amount of bad things(1). They state that in choosing between alternative actions, laws or policies we should pick the option that improves the sum total of the individuals' well-being.

During the $20^{\text {th }}$ century, in the field of health, various attempts to measure well-being objectively were developed, from the health-status indices designed before World War II to the burden of disease measurement developed in the late $20^{\text {th }}$ century. The main objection to the use of a single index to measure well-being is that it disregards individual variations in preferences(2). Some individuals, for example, would seek the longest life possible even if it involves major suffering, while others would seek to avoid extreme pain or suffering even if it entails a shorter life span.
The attempts to measure well-being provided the basis for cost-effectiveness analysis (CEA), which estimates the costs and health gains of alternative interventions(3). CEA has been extensively used in the health arena in the past decades to identify those interventions that provide the utmost improvement in health for the least resources.

CEA has been used in combination with disease burden information to define priorities. In general, conditions accounting for a high proportion of the burden of disease that can be addressed with highly cost-effective interventions are usually identified as priorities, as opposed to rare conditions for which cost-effective interventions are not available(4).

In the search for inclusive approaches to the definition of health priorities, other criteria have been used in addition to cost-effectiveness and contribution to the burden of disease, such as professional and social acceptability, which refers to the degree to which health workers and people endorse a health intervention or find it adequate or acceptable(5).

Another key component of the just definition of health priorities, in addition to specific criteria, are the procedures used to identify them. In the absence of a broad consensus on the principles for fair distribution, the problem of reasonable allocation of limited resources becomes, according to Daniels and Sabin, one of 'procedural justice', which refers to the fairness and transparency of the processes by which decisions are made $(6,7)$.

In the following sections we will describe the way in which health interventions offered by Seguro Popular were selected in Mexico during the past decade. We will first describe the objectives and content of the reform that created Seguro Popular, and then the criteria and procedures used to identify the costly interventions that would be covered by this insurance scheme.

\section{Definition of Priorities in the Mexican Health Re- form}

The design of a comprehensive health-system reform in Mexico included an explicit deliberation on the best approach to determine priorities. The 
product of this relevant discussion was a formal mechanism to identify those costly interventions that would be financed by Seguro Popular through its Fund for the Protection against Catastrophic Expenditures (FPCE). The criteria used to identify potential priorities and the procedure employed to reach agreements are discussed in this section.

\section{Objectives and ethical framework of the Mexican bealth reform ${ }^{3}$}

In 2003 the Mexican Congress approved a reform to provide social protection in health to the non-salaried population through Seguro Popular, a public insurance scheme financed predominantly through federal and state taxes( 8 ).

In 2004, Seguro Popular began full-scale implementation. Public expenditure expanded gradually to finance health coverage for approximately half of the total population. The budget of Mexico's Ministry of Health increased more than four times in real terms between 2004 and 2015. By 2018, the new insurance scheme had $53.5 \mathrm{mi}$ llion beneficiaries(9).

Seguro Popular guaranteed access to 294 common interventions included in the Universal Health Services Catalogue or CAUSES and 66 high-cost interventions financed through FPCE. Interventions included in CAUSES were provided by public clinics and general hospitals of the State Health Services, while high cost interventions were delivered by the National Institutes of Health and several high-specialty state hospitals. Salient among the interventions covered by FPCE are intensive neonatal care and treatment for all cancer in children, HIV/AIDS, breast cancer, prostate cancer, hepatitis $\mathrm{C}$, and miocardial infarction.

Given the nature of this paper, it is important to also describe the ethical platform of this reform which was explicitly discussed in the 2001-2006 National Health Program(10).

The Mexican reform was framed by a guiding concept related to the principle that health care is not a commodity or a privilege, but a social right.

\footnotetext{
${ }^{3}$ Some of the ideas presented in this section were discussed in the following paper by the same authors: Frenk J, Gómez-Dantés O. Ideas and ideals: ethical basis of health reform in Mexico. The Lancet 2009; 373: 1406-1408.
}

This concept was the 'democratization of health,' which involves the expansion of democracy to the social rights dominion.

According to O'Donnell and Schmitter, the term "democratization" entails the application of the norms and procedures of citizenship to institutions that have been ruled by other principles, such as coercive control, social tradition, judgment of specialists or bureaucratic processes(11). It also entails the application of these norms and procedures to individuals who did not enjoy the benefits and duties of citizenship, such as women, youngsters or ethnic minorities. In his seminal work, Marshall recognizes three types of rights involved in the idea of citizenship: civil, political, and social(12).

According to Brachet-Márquez, the transformation of health care into a social right basically involves the definition of the set of health interventions that all residents of a country, regardless of their labor or socioeconomic status, should receive and can legally demand(13). It also implies the definition of the procedures through which the cost of those benefits will be distributed among the different populations group in order to guarantee its financial sustainability.

As a result of its democratization process, Mexico had made substantial progress in the exercise of political and civil rights, but it was clear that the next great challenge was to amend inequalities by guaranteeing the universal exercise of social rights, including the right to health care(14). Although this right had been incorporated to the Mexican Constitution two decades earlier, in actual practice not everyone had been equally able to exercise it. Half of the population, by virtue of occupational status, enjoyed the protection of social insurance. The other half, however, was excluded. As the historian Lynn Hunt has written, "human rights are still easier to endorse than to enforce (15)".

In the Mexican case what was lacking was the definition of the explicit entitlements that ensued from the legal recognition of the right to health care, as well as the financial and organizational vehicles to translate them into effective health services for all. 
One of the most interesting aspect of Seguro Popular was that its point of departure was the definition and costing of the specific entitlements that would give operational meaning to the right to health care enshrined in the Mexican Constitution. As mentioned above, the guaranteed entitlements comprised two sets of interventions: first, a package of essential preventive and curative services for conditions of high incidence and relatively low cost, which account for the vast majority of needs and demand; second, a package of high-cost interventions for conditions with potentially catastrophic consequences for families.

An additional crucial component of the definition of the entitlements that would be associated to the affiliation to Seguro Popular was the process through which the covered health services were identified. In the following section we describe the use of a process based on Daniels and Sabin's 'accountability for reasonableness' in the selection of the costly interventions financed by $\operatorname{FPCE}(16)$.

\section{Fair selection of the costly interventions covered by Seguro Popular}

The design of the package of essential health services posed no ethical problems to the Mexican health authorities, since CAUSES included nearly all services offered in out-patient clinics and general hospitals of the federal and local departments of health. The ethical dilemmas appeared with the selection of a limited number of interventions that would be covered by FPCE. The General Health Council (GHC), a Constitutional collegiate board with national authority, was charged with the responsibility of making recommendations regarding the costly health interventions that would be covered by this fund.

Before the incorporation of the GHC to the process of selection of health interventions, a first package of costly interventions, which included treatment for leukemia in children and HIV/ AIDS, was defined for the first two years of implementation of Seguro Popular with no explicit criteria or process in place. However, by the end of 2006, a clear and fair procedure for the gradual inclusion of additional interventions was established with the aid of Norman Daniels, a professor of Ethics and Population at the Harvard School of Public Health and an expert in the topic of fair distribution of limited health resources.

The deliberative process for the selection of the costly interventions financed by FPCE was based on the work of four groups organized by the GHC: i) a clinical group, formed by physicians and nurses; ii) an economics groups, formed by health economists and epidemiologists; iii) an ethics group, formed by ethicists mostly from the National Bioethics Commission, and iv) a social acceptability group, which included individuals from various professions and NGO representati$\operatorname{ves}(17)$.

The approved mechanics of the process were the following. The clinical and economics groups would evaluate a set of interventions proposed by the GHC using as criteria their prevalence, severity (mortality rate), course of the disease, cost, and cost/effectiveness. The information and recommendations generated by these groups would then be discussed by the ethics group, which would then provide its own recommendations to the GHC. The Council would then discuss the inputs provided by these three groups and make its own preliminary recommendations. Finally, these recommendations would be discussed by a group of stakeholders assembled by the social acceptability group. With the inputs from the four groups, the GHC would make a recommendation to the National Commission on Social Protection for Health, the governing body of Seguro Popular.

The approved process respected the four conditions of 'accountability for reasonableness': i) publicity condition; ii) relevance condition; iii) revision and appeals conditions; and iv) regulative condition $(16,17)$. The publicity condition was met because all criteria used for deliberation and the final coverage decisions were made publicly available. The involvement of a proper group of stakeholders and the successive discussions by various groups assured that the criteria used to develop the recommendations were based on reasons that all actors considered relevant. The decisions could be revised in light of new evidence, such as changes in the prevalence of diseases and the availability of new effective treatments and their impact on cost-effectiveness. Finally, the adherence to these three conditions was guaranteed by the 
authority of the Ministry of Health, the GHC, and the National Commission on Social Protection for Health.

This process was in place for six years after its approval by the GHC, with acceptable results, making it, according to Daniels, the first example of the use of 'accountability for reasonableness' for priority setting in developing countries.

\section{Conclusions}

Several conclusions can be derived from this experience. First, the use of an ethical framework in the design and implementation of public policieswhich includes explicit values, explicit criteria for the definition of priorities, and fair processes for their identification-increases their acceptability and can contribute to their eventual success.

The second conclusion is that the idea of a package of health services, traditionally an instrument of technocratic approaches to health care, can be used in reform processes that emphasize equity and social justice. In the Mexican reform, costeffectiveness analysis was used to select the interventions that would be covered by FPCE, but it was complemented with additional criteria, such as ethical considerations, and social and professional acceptability. An additional advantage of health packages in relation to equity is that they empower health care users by making them aware of their entitlements.

The final conclusion is that in the absence of a broad consensus on the criteria to identify health priorities, the use of a transparent and fair process is crucial to guarantee the legitimacy of public policies.

To sum up: the Mexican experience discussed shows that it is possible to reconcile two extremes of the health care arena, the technocratic approach to the distribution of health care, which offers practical alternatives but purports to be morally neutral, and the rights-based approach, which has a strong value foundation but has lacked operational support(18). 
Ethics and Public Health: definition of priorities in the Mexican Health Reform - Octavio Gómez-Dantés, Julio Frenk

\section{References}

1. Internet Encyclopedia of Philosophy. Act and rule utilitarianism. Available at: https://www.iep.utm.edu/util-a-r/. Accessed March 4, 2020.

2. Roberts MJ, Hsiao W, Berman P, Reich MR. Judging health sector performance. Ethical theory. In: Roberts MJ, Hsiao W, Berman P, Reich MR. Getting Health Reform Right. A Guide to Improving Performance and Equity. Oxford: Oxford University Press; 2004: 40-60.

3. World Health Organization. Cost-effectiveness analysis for health interventions. Available at: https://www.who.int/heli/ economics/costeffanalysis/en/. Accessed March 3, 2020.

4. Musgrove P, Fox-Rushby J. Cost-effectiveness analysis for priority setting. In: Jamison DT, Breman JG, Measham AR, Alleyne G, Cleason M, Evan DB, et al., editors. Disease control priorities in developing countries. New York: Oxford University Press; 2006: 271-285.

5. Cohn S. Reconceptualizing social acceptability: A study of the ways people respond to policies aimed to reduce alcohol consumption. Health 2016; 20(3): 203-219.

6. Daniels N, Sabin JE. Setting limits fairly. Can we learn to share medical resources? New York: Oxford University Press; 2002.

7. Bennett S, Hine L, Mazerolli L. Procedural justice. Oxford Bibliographies (April 26, 2018). Available at: https://www. oxfordbibliographies.com/view/document/obo-9780195396607/obo-9780195396607-0241.xml. Accessed March 5, 2020 .

8. Frenk J, González-Pier E, Gómez-Dantés O, Lezana MA, Knaul FM. Comprehensive reform to improve health system performance in Mexico. The Lancet 2006; 368: 1524-34.

9. Sistema de Protección Social en Salud. Informe de Resultados. Enero-Diciembre 2015. Available at: http://www.transparencia.seguro-popular.gob.mx/contenidos/archivos/transparencia/planesprogramaseinformes/informes/Informe\%20de\%20 Resultados\%20Ene-Dic\%202015.pdf. Accessed March 6, 2020.

10. Secretaría de Salud. Programa Nacional de Salud 2001-2006. La democratización de la salud. Hacia un sistema de salud universal. Mexico City: Secretaría de Salud; 2001.

11. O’Donnel G, Schmitter P. Transiciones desde un gobierno autoritario. Buenos Aires: Paidos; 1991: 22-23.

12. Marshall TH. Class, citizenship and social development. New York: Doubleday Anchor Books; 1965.

13. Brachet-Márquez V. Ciudadanía para la salud: una propuesta. En: Uribe M, López-Cervantes, editores. Reflexiones acerca de la salud en México. México, D.F.: Médica Sur, Editorial Panamericana; 2001: 43-47.

14. Sen A. Why and how is health a human right? The Lancet 2008; 372: 2010.

15. Hunt L. Inventing human rights. A history. New York and London: WW Norton \& Company; 2007: 208.

16. Daniels N, Sabin JE. Accountability for reasonableness. In: Daniels N, Sabin JE. Setting limits fairly. Can we learn to share medical resources? Oxford: Oxford University Press; 2002: 43-66.

17. Daniels N. Using accountability for reasonableness in developing countries. Two applications. In: Daniels N. Just Health. Meeting Health Needs Fairly. Cambridge: Cambridge University Press; 2008: 274-296.

18. Frenk J, Gómez-Dantés O. Ideas and ideals: ethical basis of health reform in Mexico. The Lancet 2009; 373: 1406-1408.

Received: April 13, 2020

Accepted: April 27, 2020 